Матеріали Всеукраїнської науково-практичної конференчії «Актуальні питання діагностики, лікування, рачіональної фармакотерапії, диспансеризачії та реабілітації в практиці сімейного лікаря»

DOI

\title{
РАННІ МАРКЕРИ СИСТЕМНОГО АТЕРОСКЛЕРОЗУ У ХВОРИХ МОЛОДОГО ВІКУ, ЯКІ ПЕРЕНЕСЛИ ГОСТРИЙ ІНФАРКТ МІОКАРДА
}

๑В. Р. Микуляк, Л. В. Зоря, Н. І. Трач

ДВНЗ «Тернопільський державний медичний університет імені І. Я. Горбачевського МОз України»

На сьогоднішній день доведено, що товщина комплексу інтима-медіа (КІМ) - важливий предиктор розвитку серцево-судинної та церебральної патології.

Метою дослідження була оцінка стану КIM сонних артерій для виявлення в них ранніх атеросклеротичних змін у хворих, які перенесли гострий інфаркт міокарда (IM).

На поліклінічному етапі обстежено 26 хворих, які перенесли гострий IM. У дослідження були включені лише особи чоловічої статі, вік яких не перевищував 45 років. Середній вік хворих склав $(43,64 \pm 0,32)$ років. Паралельно обстежено 20 практично здорових осіб відповідного віку. Обстеження проведено через 3 місяці після перенесеного IM. Товщину КІМ вимірювали за допомогою ультразвукового сканера «Aloka 5000» (Японія) лінійним датчиком з частотою сканування 7,0 МГц у повздовжньому перерізі на відстані 1 см від біфуркації сонної артерії, нормальною вважали товщину менше 0,9 мм.
У 42,3 \% обстежених хворих виявлено ранні ознаки атеросклерозу у сонних артеріях. Товщина KIM у пацієнтів, які перенесли гострий IM, достовірно перевищувала значення контрольної групи і, відповідно, становила $(1,08 \pm 0,07)$ мм проти $(0,82 \pm 0,02)$ мм у практично здорових осіб. У 26,4 \% хворих виявлено атеросклеротичні бляшки сонних артерій, що свідчить про виражені зміни судинної стінки і, відповідно, високий кардіоваскулярний ризик. Найчастіше атеросклеротичні бляшки спостерігали у курців з інтенсивністю паління понад 10 пачко-років та у хворих із супутнім цукровим діабетом 2 типу.

Отже, в результаті дослідження встановлено, що у частини пацієнтів молодого віку, які перенесли гострий IM, уже $є$ ознаки системного атеросклерозу. Це група пацієнтів із дуже високим кардіоваскулярним ризиком, яким для запобігання наступним серцево-судинним подіям необхідне ретельне спостереження та більш агресивна лікувально-профілактична тактика. 